\title{
The cost of community-based action research: Examining research access and implementation through the Food Dignity project community support package
}

\section{FoodDignity}

\author{
Gayle M. Woodsum * \\ Action Resources International and Feeding Laramie Valley
}

Submitted July 9, 2018 / Published online July 18, 2018

Citation: Woodsum, G. M. (2018). The cost of community-based action research: Examining research access and implementation through the Food Dignity project community support package. Journal of A griculture, F ood Systems, and Community D evelopment, 8(Suppl. 1), 83-99. https:// doi.org/ 10.5304/jafscd.2018.08A.021

Copyright (C 2018 by the Author. Published by the Lyson Center for Civic Agriculture and Food Systems. Open access under CC BY license.

\section{Preface}

I had the distinct honor of serving two roles in the Food D ignity research project. From the spring of 2010, when I was initially contacted by Christine Porter and invited to contribute thinking and feedback for her Food Dignity grant application, through completion of the project in March 2016, I served as the project's director for the community partner site in Laramie, Wyoming, Feeding Laramie Valley. In addition, between March 2011 and September 2013, I played a small, minimally funded role in providing projectwide consulting and support to Christine, the project's principle investigator (PI) and director. Halfway through Y ear 3 of the project, in fall 2013, this role expanded and developed into that of projectwide community liaison- one which I retained through the end of the project's 7th no-cost extension year

* Gayle M. Woodsum, President/ CEO , Action Resources International; community-university liaison, Food Dignity; founder, Feeding Laramie Valley; P.O . Box 536; Laramie, WY 82073 USA; gayle@ actionresources.ngo in March 2018 and its completion. I continued to provide direction and oversight for Feeding Laramie Valley's position as a community-based organization (CBO) partner in the project while serving as community liaison, but the role of community organizer for FLV and its research obligations were carried out by FLV program staff leadership. Carrying this multilevel responsibility and dual perspective within the project was inspiring, enlightening, and at times challenging for me. I interpreted and carried out my community liaison position as being one of advocacy for and on behalf of all the community members involved

\section{Funding Disclosure}

Food Dignity (http:/ / www.fooddignity.org) was funded by U.S. D epartment of Agriculture-National Institute of Food and Agriculture's Agriculture and Food Research Initiative Competitive Grant no. 2011-68004-30074.

\section{Contributors and Supporting Agencies}

Blue Mountain Associates; Dig D eep Farms; East New York Farms!; Feeding Laramie Valley; Whole Community Project; U.S. D epartment of AgricultureNational Institute of Food and Agriculture. 
directly and indirectly with the Food Dignity research project across the country. My decades of experience as a community-based writer and activist (since the early 1980s) guided and motivated me with clarity on whose behalf I was working. My role as project community liaison allowed me to get to know nearly all the individuals involved with the project, to spend time learning about their work, their philosophies, and the challenges they were presented with through their involvement with Food Dignity. Almost without exception, every individual with whom I worked, community member and academic alike, honored me with a willingness to be open, honest and diligently hard-working in fulfilling their obligations to Food D ignity. Every community member who contributed to the project, and most especially the leaders of its community partner sites, followed through with their project obligations while remaining true to their extraordinary commitments and allegiance to the communities on whose behalf they served. They never wavered in the social justice underpinning of their work and the 24/ 7 brilliance, time, and caring they gave to it, and I will be forever grateful for what I learned from each and every one of them.

\section{Acknowledgments}

I had the great fortune to work closely with Monica Hargraves and Cecilia D enning in gathering, organizing, and disseminating the final Food Dignity findings. Their insightful analysis and deep respect for first-person expertise has been constant. Finally, these acknowledgments would not be complete without recognition for the creativity and dedication of the Food Dignity action research project's initiator and PI, Christine Porter. Throughout a long and complex implementation process, she maintained a deep commitment to support and respect the rigorous frontline contributions of the project's community partners.

\section{Keywords}

Community-based Participatory Research; Action Research; Food Justice; Community Activism; Social Justice; Community-Academic Partnerships; Equity

\section{Introduction}

There's a world of difference between research funding awarded to institutions of higher learning and what goes for standard program support funding available to the average nonprofit community-based organization (CBO) - in particular, grassroots efforts defined and guided by the constituency living with the problems being addressed. Beyond a baseline difference between research grants that ask questions and program grants that provide services in response to identified needs, access to and internal functioning of research grants versus program grants are often diametrically opposed. On a practical level, research funding is far more likely than CBO funding to provide multiple-year support and large budgets that allow funds to be used for personnel and indirect costs. Very few research opportunities are offered directly to $\mathrm{CBO}$ s, with eligibility typically limited to colleges, universities, and other so-called institutions of higher learning. Y et, while CBOs are commonly shut out of major research funding pools at the outset, they are increasingly required to provide an approved "evidence base" to justify funding for the program services they provide. This requirement forces them to draw on information-gathering and analysis processes from which they are essentially excluded.

Beyond the obvious, there are subtle distinctions to be made between the researcher's hunger to explore and expose deep roots beneath the human condition that can lead to the elevation of knowledge, and the activist's hunger to ad on deeprooted knowledge of the same human condition. Research can open doors to revelations that may or may not be acted upon. G rassroots activism is most often propelled by raw knowledge originating from first-person experience, mining that very specific expertise and contextualizing it for the primary purpose of creating social change as it can be lived day to day.

Historically, the standard research paradigm not only operates within a frame of objectivity and disinterest as accuracy and rigor; it also promotes these ideals as being essential standard-bearers in a hierarchical view of expertise. This view rewards the researcher in a quest for knowledge for its own sake and diminishes frontline activism by 
marginalizing first-person expertise and limiting grassroots access to leadership roles in research that supports action. Knowledge hierarchy, as a concept backed by the academy, is largely unchallenged by policy makers and funders. This creates and maintains a functional power gap between researchers and activists.

Community-based participatory research attempts to minimize that gap by creating collaborative efforts between the academy and $\mathrm{CBO}$ s. As well-intentioned and even passionate the goal for equitable collaboration might be, research leadership, funding, and eligibility access, as well as all the privileges that accompany them, remain severely limited for CBOs.

In the spring of 2010, Christine Porter, having recently received a $\mathrm{Ph} . \mathrm{D}$. in community nutrition from Cornell University, began the application process for an Agriculture and Food Research Initiative (AFRI) grant from the USD A National Institute of Food and Agriculture. Having conducted much of her doctoral research on the relationship between food and public health, Christine was finding herself increasingly interested in and drawn to the development of community food systems work being done at the grassroots level in response to a range of issues related to food security. The call for proposals through the USDA-AFRI initiative at that time appeared to Christine to offer an opportunity for a much deeper exploration of how communities were experiencing and responding to challenges of local food insecurity. She embarked on the development of an application, drawing on input and assistance from her academic and community colleagues and mentors, and national leaders in food systems activism. She also drew input from a diverse mix of CBO s across the country that she was referred to or sought out as potential community-based sites. These sites would serve as the core sites from which project data would be derived.

With her newly minted doctoral degree in hand, Christine's debut application for major research funds was successful, naming her as

\footnotetext{
1 The term F ood D ignity in the project's name was inspired by E. Jemila Sequeira in conversation with Christine regarding community needs connected to food security. More on that
}

principal investigator and project director on the project she named F ood D ignity: A ction Research on E ngaging $\mathrm{F}$ ood Insecure $\mathrm{C}$ ommunities and $\mathrm{U}$ niversities in Building Sustainable C ommunity F ood Systems. ${ }^{1}$ As a result, on April 1, 2011, several dozen people spread across various parts of California, Wyoming, and New York embarked on the five-year, US\$5 million Food Dignity action research project. Key academic partners included the University of Wyoming as the lead institutional grant administrator--also serving as Christine's new employer and her research base; Cornell University; Ithaca College; and UC D avis. There were also five CBO s and community leaders holding key partnerships: Dr. Virginia Sutter of Blue Mountain Associates, Wind River Indian Reservation, Fort Washakie, Wyoming; Captain Martin Neideffer, Dig D eep Farms, D eputy Sheriff's Athletic League, AshlandCherryland, California; D irector Sarita D aftarySteel, East New York Farms!, United Community Centers, East New York, New York; Founder Gayle Woodsum, Feeding Laramie Valley, Action Resources International, Laramie, Wyoming; Director, Jemila Sequeira, Whole Community Project, Cornell Cooperative Extension of Tompkins County, Ithaca, New York.

To its credit, the Food Dignity action research project design was developed and submitted for funding consideration with some unique equityseeking aspects between the academic and community partners. All five community partner sites were consulted not just for their interest in and willingness to participate in the study, but for feedback on the overall research vision and design fashioned by Christine, and for extensive input into crafting their own individual scope of work within that vision. While the final drafting of the project's narrative and the identification of the budget line items and their associated justification was solely under Christine's direction and final approval, her establishment of a dedicated community support package for each of the project's community partner sites reflected, at the outset, a clear commitment to the core importance of the sites' roles in the

story can be read in this issue (Sequeira, 2018) and seen in a video story (Porter, 2015). 
project. It also reflected recognition of the value of their knowledge and expertise to be shared with the project and acknowledgment of the financial support needed by each CBO in order to carry out their project commitments.

The motivation for agreeing to participate in the Food Dignity research project varied in detail among the leaders of each community partner site. These motivations can be explored further in the series of introductory articles featured in this JAFSCD special issue from all five of the CBO s (D aftary-Steel, 2018; Neideffer, 2018; Sequeira, 2018; Sutter, 2018; Woodsum, 2018). As a general common theme, the leader of each CBO cited an opportunity to advance their core mission and the community support package (in particular line items that supported personnel and administrative costs, as well as the five-year length of that support) as contributing factors in the decision to join the project. As the project played out, and as this paper discusses, the flexibility inherent in the community support package--an aspect that was also developed along the way-- became a crucial contributor to the level of commitment and depth of contributions possible from the community partner sites.

\section{Community Organizing and Program Strategies of the Community Partners}

As written in the Food Dignity project proposal in 2010, "the goals of this integrated project [were] to identify, develop and evaluate community organizing strategies for sustainable food systems (SFS) for food security (FS) while expanding university, community, and individual capacities to catalyze, support and research SFS for FS." Tedious initialisms aside, there were two predominant aspects of the action research built into the project at the outset that reflected its intention to amplify community-based knowledge. The first was the focus on community organizing strategies, reflecting an acknowledgment that participating $\mathrm{CBO}$ s (identified at the time the grant application was submitted) already had leadership roles dedicated to identifying need and to mobilizing resources through a focus on sustainable activism. The second aspect was for the project to act as a catalyst, provide support, and expand research- this subsequent key component is clearly linked to the first.

As proposed, the Food D ignity project presented itself as a plan for action research to be conducted as much by communities as it was about them, casting the academic role as one of a supportive partner rather than an extractive autocrat. The invitation for specific CBOs to join the project was based in part on each community site's existing accomplishments in addressing food insecurity through sustainable food systems efforts. It was also based in part on their confirmed capacity to carry out the research needs of the project itself.

Each of the five community partner sites joined the project with a mission and philosophy established, along with a key person in place providing leadership for their implementation. There was intentional diversity among and between the sites, including in geographical location; community demographics (organizational, micro, and macro); organizational philosophy; and management design. Program strategies- types and longevity - varied within and between sites. They were typically in keeping with the unique attributes of each site, as listed above, and were, in particular, reflective of the specific community needs being addressed. Brief descriptions of the intervention strategies (i.e., programmatic efforts designed and implemented in response to community needs in relationship to sustainable food systems for food security) put in place or envisioned by each of the Food Dignity project community partners at the time the project was officially launched are provided in sidebars in this piece. D escriptions were adapted from each community partner's own promotional materials and presentations.

Each of the five Food Dignity community partners quickly distinguished themselves individually- not only through the unique sustainable food systems projects in which they were engaged, but by presenting an identity borne of their individual and traditional roots of activism driving them to face challenges directly and on the front line. For Blue Mountain Associates, it's a combination of historical trauma and the Wind River community's health challenges (including an average life expectancy of 49 and high rates of diabetes) that serve as an impetus for reclaiming 
traditional ways of pursuing community health. Dig D eep Farms organizes for sustainable food security in a community locale that annually feels the impact of 8,000 formally incarcerated people entering an unincorporated urban environment. Dig D eep Farm's home organization, D eputy Sheriff's Activities League (D SAL), holds steadfastly to the idea that collaboration and enrichment for building community safety is part of successful community policing. East New York Farms! works with the multicultural needs of immigrant community members and dozens of young people every year in an atmosphere of humility and unhindered appreciation. Feeding Laramie Valley moves forward with community building that blurs the lines between giver and receiver in a way that honors lived experience as first-person expertise. Whole Community Project's legacy is the advancement of proactive efforts to ensure truly diverse voice and leadership representation at every level of food systems assessment, including policy making and opportunity development.

\section{Project and Design Intention of the Food Dignity Community Support Package}

Individually, the community partners of the Food Dignity action research project were strong, independent agents of change. They were well accustomed to forging new paths on their own and with extremely limited recognition or support. Then, in
April 2011, they added to their own operations by signing on to be part of a national venture that promised to be larger than the sum of its individual contributions. They would each receive a complex list of deliverables expected to submitted over the next five years (and which would require bringing in new organizational roles and people to fulfill them); they would also be required to attend and contribute extensively to seven all-team meetings held in varying parts of the country (five of which corresponded with the locations of the community sites and two others located in key parts of the country involved with distinguished sustainable community food systems efforts); and each community partner would find every aspect of the work they were doing affected by their new key role in the Food D ignity project. In return, each site would be awarded financial support in the form of a community support package, which they would subcontract with the University of Wyoming on an annual basis (see Table 1).

\section{Projectwide View of an Evolving Community Support Package}

The five community partners entered into the Food Dignity research project without extensive previous knowledge of or direct, working connection to one another. While, to varying degrees, each provided feedback and made suggestions regarding their scope of work and how it could best align

Blue Mountain Associates, Wind River Indian Reservation, Wyoming.

Blue Mountain Associates (BMA) has a background in community health services, support, and program implementation on American Indian reservations. BMA was developing specialized, local sustainable food systems programs for the Northern Arapaho and Eastern Shoshone tribes of the Wind River Indian Reservation in Wyoming when they joined the Food Dignity research project. Through education, collaboration, and action research, their programs seek to fulfill organizational goals that include: expansion of sustainable community food system (SCFS) work to increase food security (FS); increased substantial involvement of and leadership from community members facing food insecurity in SCFS work; learning from the community's own past history and ongoing work, including research methods and other partners in this project, to improve a SCFS on the reservation; and expanding their organizational capacity and the communities' civic infrastructure for building food security and agency. Specific programs used to reach these goals throughout the Food Dignity research project included: mentoring, guidance, and support for community-developed projects that increased community food access and security as well as local economic development; the implementation of weekly farmers markets held in various locations across the reservation, at which beginning farmers and gardeners had the opportunity to be involved as sellers; and the development, installation, support, and action research study of backyard gardens and gardeners. 


\section{Table 1. Food Dignity Community Support Package Categories as Originally Proposeda}

General allocation note: The budget was designed on a graduated basis from year to year. Some line items increased each year (such as the one for the community organizer), while others waxed and waned according to project requirements in any given year (e.g., minigrant funds started low, peaked in Years 2-3, and ended after year 4; materials and supplies allowed for upfront expenditures in Year 1 to enable the site to invest in project-necessary items). The range of funding levels between sites at the time of the grant award were the result of geographically-based average salary range differences for the community organizer, line item funding unique to a particular site (e.g., farmers market management funds for BMA; annual stipend of US $\$ 3000$ for campus-community coordination and placement and internship stipends for FLV and WCP the two sites located in the same community as major university partners University of Wyoming and Cornell University. These line items not shown in the table below and are excluded from the Community Support Package totals for those two partner sites in the final row and in the percentage calculations).

\begin{tabular}{|c|c|c|c|}
\hline $\begin{array}{l}\text { Line Item Category } \\
\text { Salaries and Wages }\end{array}$ & $\begin{array}{l}\text { Annual Amount } \\
\text { (US\$) }\end{array}$ & $\begin{array}{l}\text { \% of Annual } \\
\text { Community Support } \\
\text { Package Budgetc }\end{array}$ & Notes \\
\hline Senior/Key Person & $\$ 0-\$ 8,573$ & $3 \%$ & $\begin{array}{l}\text { In most cases, the senior and/ or key person held an } \\
\text { unfunded position of oversight for a particular } \\
\text { community partner site. One site allocated funds to the } \\
\text { key person and the project's community organizer. }\end{array}$ \\
\hline $\begin{array}{l}\text { Community } \\
\text { Researchers }\end{array}$ & $\$ 5,000-\$ 16,000$ & $20 \%$ & $\begin{array}{l}\text { Community researchers were written into the grant as } \\
\text { individuals capable of being trained to supplement data } \\
\text { collection and deliverable product development. }\end{array}$ \\
\hline Community Animators & $\$ 1,000-\$ 4,000$ & $5 \%$ & $\begin{array}{l}\text { A line item for community animators was included in } \\
\text { Years 1-4 for four sites as additional assistance to } \\
\text { community efforts for developing and facilitating } \\
\text { learning programs that support action for local and } \\
\text { social change. The remaining site used these funds to } \\
\text { support a Farmers Market Manager position. }\end{array}$ \\
\hline $\begin{array}{l}\text { Community Organizer } \\
\text { (50\% FTE) }\end{array}$ & $\$ 20,000-\$ 28,143$ & $40 \%$ & $\begin{array}{l}\text { The largest portion of each community support package } \\
\text { went toward funding a } 50 \% \text { full-time equivalent position } \\
\text { for a community organizer, a role designed to take the } \\
\text { lead on fulfilling the site's project and grant } \\
\text { requirements. }\end{array}$ \\
\hline \multicolumn{4}{|l|}{ Other Direct Costs } \\
\hline Travel & $\$ 1,100-\$ 2,335$ & $3 \%$ & $\begin{array}{l}\text { Travel funds were allocated to the community sites to } \\
\text { directly support their attendance and presentations at } \\
\text { educational conferences and events. }\end{array}$ \\
\hline
\end{tabular}

Participant Support

Costs

\begin{tabular}{|c|c|c|c|}
\hline Stipends & $\$ 750-\$ 3,150$ & $3 \%$ & $\begin{array}{l}\text { The grant application called for the formation of a } \\
\text { community steering committee as part of the project } \\
\text { implementation. The budget allowed for stipends to be } \\
\text { paid for meeting attendance. }\end{array}$ \\
\hline Travel & $\$ 500-\$ 4,000$ & $3 \%$ & $\begin{array}{l}\text { Funds were budgeted for mileage and other travel } \\
\text { reimbursement costs for community member } \\
\text { participation in meetings, trainings, and project-related } \\
\text { conferences. }\end{array}$ \\
\hline Other & $\$ 250-\$ 500$ & $1 \%$ & $\begin{array}{l}\text { A small amount was budgeted to cover miscellaneous } \\
\text { additional participant support costs. }\end{array}$ \\
\hline $\begin{array}{l}\text { Materials and } \\
\text { Supplies }\end{array}$ & $\$ 2,000-\$ 8,000$ & $5 \%$ & $\begin{array}{l}\text { The original grant application included expectations that } \\
\text { a formal photovoice project be conducted by each site, } \\
\text { utilizing community members as photographers. Supply } \\
\text { funds were budgeted to include the capacity for each } \\
\text { site to purchase multiple cameras in Year } 1 \text {. (continued) }\end{array}$ \\
\hline
\end{tabular}


Journal of Agriculture, Food Systems, and Community D evelopment ISSN: 2152-0801 online

https:/ / www.foodsystemsjournal.org

\begin{tabular}{lll}
\hline Minigrants $\$ 1,000-\$ 10,000$ & $9 \% \quad \begin{array}{l}\text { Each community partner site was allocated } \$ 30,000 \\
\text { total over the course of the 5-year Food Dignity project } \\
\text { for the development of a minigrant funding program to }\end{array}$ \\
$\begin{array}{ll}\text { community member food projects (funds were budgeted } \\
\text { in Years 1-4 and unused funds could be rolled over). }\end{array}$
\end{tabular}

Indirect Costs

$10 \%$ Indirect

$\$ 4,348-\$ 6,464$

$10 \%$

Between the application process and the actual grant

(of Total Direct

Costs)

award, indirect costs were disallowed for the community

partner sites. The funds were re-allocated into the

salaries and wages category and designated as Sub-

Award Project Manager.

Total Support Budget $\quad \$ 47,828-\$ 67,669$

The annual support package as originally proposed

(excluding internranged per site between $\$ 49,918-\$ 60,610$ in Year 1

related line items for and between $\$ 51,735-\$ 67,669$ in Year 3 , the highest

WCP and FLV) funded year of the project when the peak of minigrant funding was made available.

a For details on projectwide funding for the Food Dignity research project, see the article in this issue, "Follow the Money: Resource Allocation and Academic Supremacy among Community and University Partners in Food Dignity" (Porter \& Wechsler, 2018).

$\mathrm{b}$ The range reports the lowest and the highest allocated amount, at any site across all years.

c Averaged over all years and all sites.

with how the project would play out, there was one overall research design assigned to all five groups. The primary aim of the community support package was to ensure that the cost of participation in the project would be covered by the grant. This included the proposal's assertion (as noted in the Organizing and Programming Strategies section earlier in this paper) that the community support package be a catalyst for identifying, developing, and evaluating community organizing strategies for sustainable food systems (SFS) for food security (FS), as well as the assertion that the it would serve to expand individual capacity for doing the same. It was clear that the grant was not designed to provide $100 \%$ funding to any of its community partners. What could not have been anticipated was that, while Food Dignity project funding initially appeared as though it should cover the sites' costs for living up to their project-related obligations, the ultimate reality of the complexity and level of work required of the partner sites extended beyond what the grant actually paid for.

Although community partners had provided extensive input into crafting their individual scopes of work, they had not been included in the initial budget development process for the overall project, nor in determining their individual level of funding within the project other than determining salary rates of the community organizers. The originally proposed budget was established by Christine Porter at the grant-writing phase. As PI and project director, she retained control over the overarching project budget and pre-approval of each subaward, within the parameters and regulations set by USD A-AFRI and the proposed scope of the project.

The differences between how the Food Dignity research project was designed and how it played out revealed themselves early in the implementation process, with many of them connected one way or another to how funds were budgeted and then how they were utilized. To varying degrees, the infusion of Food D ignity project funds into the budgets of community partners changed the level of their capacity to function and grow. This capacity was also influenced by individual factors at each location.

Blue Mountain Associates (BMA), Wind River Indian Reservation; Dig D eep Farms (D D F), Ashland-Cherryland, California; and Feeding Laramie Valley (FLV), Laramie, Wyoming, were all operating community food systems programs that were relatively new.

Of those three sites, DDF was the only one to have secured government and/ or foundation funding at a level capable of supporting program capacity-building-- such as program staff--prior to joining the Food D ignity project. Yet, in spite of its 
placement within the supportive infrastructure of the Alameda County Sheriff's office, the Food Dignity grant funds quickly became D D F's primary program funding source for a time (see the introductory essay on D DF by its director, Marty Neideffer, [N eideffer, 2018], in this issue).

While BMA brought years of community health experience with many Native First Nations across the western United States, including with its founder's own tribal community in the Wind River Indian Reservation, joining the Food Dignity project provided the shaping force for BMA's sustainable food systems work for food security and nearly its entire program budget for most of the research project.

Feeding Laramie Valley had launched its collaborative sustainable food systems work for food security in 2009, but changed sponsors in 2010. By the time it began its partnership with the Food Dignity action research project, its operational support consisted of 100\% community-based volunteer labor and a few agriculturally based local and state program grants ranging in size from US $\$ 3,500-\$ 24,000$. Receiving the community support package that came along with participating as one of the community sites provided predictable financial support for some of its operations for the first time in FLV's brief existence.

East New Y ork Farms! (ENYF!) of East New York, New Y ork, joined the Food D ignity project with the least amount of crossover need for the project's funding to support or advance its existing or planned operations. At the start of the Food Dignity project, ENYF! had been working for sustainable food systems for food security for nearly 13 years. The organization had long term experience with procuring, managing, and leveraging ongoing funding for its frontline programming. It also had a baseline administrative infrastructure in place. Ultimately, ENYF!'s experience and infratructure enabled the organization to join the Food Dignity research project as much more of a purely add-on opportunity to explore new dimensions and potential expansion of its efforts while contributing to the body of knowledge on community food systems work overall.

Whole Community Project (WCP) joined the Food Dignity project as part of Cornell

\section{Dig Deep Farms, Ashland-Cherryland, California}

Dig Deep Farms and Produce (DDF) was founded in 2010 (just a year prior to joining the Food Dignity research project as a community partner site) by residents of the Ashland and Cherryland communities of unincorporated Alameda County in partnership with the Alameda County Sheriff's Office and the nonprofit Deputy Sheriffs' Activities League (DSAL). DDF is a nonprofit, social enterprise founded on the conviction that integrated community involvement, healthy food access, and job creation raise the quality of life- - individually and collectively- - of a community. Dig Deep Farms launched with the vision of becoming a network of integrated food businesses that provides access to healthy food and jobs in the local community where access to both has historically been limited. Through the course of their participation in the Food Dignity research project, DDF's program services included the following: (1) the development of two neighborhood production gardens and one large-scale orchard, berry, and produce farm; (2) the development and operational success of farm stands in partnership with the Alameda County Social Services Agency, through which they provide access to fresh, organic, and healthy foods at two different Social Service and County Administration buildings, and in part source pesticide-free produce from small farmers in the Central Valley to support local and sustainable agriculture; (3) the development of food hub- style entrepreneurial pipeline opportunities for food-related businesses, groundbreaking on a food hub site designed to increase food access through area-wide distribution; and (4) the creation of DDF retail food products featuring DDF produce. At its core, DDF added a unique core and conviction to the mix of community partners in the Food Dignity research project, by presenting itself as believing that community-engaged sustainable food systems work can be an integral part of effective, innovative community policing. As Dig Deep Farms self-proclaims about the starting line for its unique vision: "Residents wanted to start community gardens. The Sheriff's Office wanted to reduce crime and recidivism. Dig Deep Farms blossomed from the alchemy between the two." 
University's Cooperative Extension program in Ithaca, New York, carrying forward its support of community development special projects work. Being housed in a sizable and successful cooperative extension agency provided WCP with the largest and what appeared initially to be the most secure administrative infrastructure support of any of the Food Dignity community partner sites. WCP, led by Jemila Sequeira, directly invested much of its time and financial resources in developing, coordinating, and confronting the social justice and awareness aspects of Sustainable Food Systems for Food Security work in Tompkins County. On a practical level, the strategies needed for this work did not always align well with the budget structure of the Food Dignity community support package as originally delineated.

In the spring of 2011, when the Food Dignity action research project was officially launched and its five-year, US\$5 million budget was about to be utilized, the implementing team included the following combination of factors. On the one hand, there were five diverse community-based social action programs serving as project partner sites. Each was dedicated to their individual program intervention strategies while also being committed to stepping up as key contributors to a national action research project designed to report those strategies (and their effectiveness) to the world. In addition to their expertise and experience, they brought with them a range of guardedness resulting from their knowledge of the historical inequities rife between researchers and their research subjects. On the other hand, there was an academic team that controlled the research design, the majority of the funding, and all deliverable requirements, and was accustomed to having expectations of how things would proceed.

Given these divergent yet equally resolute perspectives, it should come as no surprise that the Food Dignity project followed an unpredictable, sometimes contentious path as it unfolded. Given the detailed, five-year length of each community partner's budget and associated requirements, it should have been equally predictable that each community partner site would begin to look for changes, adjustments, and increases in the community support package in search of a means to address the differences between the academic perspective and the reality faced by communitybased organizations.

\section{Community Partner Funding Choices}

There were two ways in which the frontline work of community partners in the Food Dignity project chafed against the project's design and strictures.

East New York Farms!, East New York, New York

The mission of East New York Farms! (ENYF!) is to organize youth and adults to address food justice in the East New York community by promoting local sustainable agriculture and community-led economic development. ENYF! is a project of the United Community Centers in partnership with local residents. They've been working with youth, gardeners, farmers, and entrepreneurs to build a more just and sustainable community since 1998. During the Food Dignity research project, their programs included community gardens throughout East New York neighborhoods, many of which produced food for ENYF! farmers markets, and were supported with workshops, resources, and assistance from ENYF-engaged youth; an annual, intensive, nine-month youth internship program for 35 young people who engage in hands-on learning centered around environment, health, community development, leadership, and social justice; community education in which community educators provide cooking demonstrations, presentations, and gardening workshops to educate residents about how to grow, prepare, and preserve healthy food; operation of three urban farms and one garden in East New York to increase access to locally grown produce, as well as to provide opportunities to learn, gather, and volunteer; two community-run farmers markets making fresh food available and affordable, while building the local economy and creating places for neighbors to meet and greet; and a composting program through which food scraps are collected year-round to process into nutrient-rich compost for farms and gardens in East New York to grow organic produce. 
One was the distance and difference in perspectives and experience between project team members associated with the academic side of the project, and those whose primary work was connected to frontline roles as community leaders, activists, and advocates. The other manifestation of how conflict arose and required attention, was the recognition that the line item details of the community support package had to be translated, adjusted and in some cases modified or fully changed in order to have the project's aspirations (both research and community support-related) align with the core mission and existing intervention strategies of each site.

Both categories of core challenge between the academic and community sides of the Food Dignity project team quickly rose to the surface. Beginning with the first meeting of the full project team held in May 2011 in Ithaca, New Y ork, conversations between community partners and members of the academic team were fraught with conflicting expectations and styles of communication. The conflict that surfaced at that meeting remained and even grew in multiple directions throughout the duration of the project. To fully explore the origin, consequences, and significance of that internal conflict is beyond the scope of this paper, but the discussion below highlights ways in which this core conflict played out in the evolution of the community support package

Tracking the use and modification of the community support package for each community partner site is a means of following some of the ways in which those sites leveraged their own power and knowledge to more effectively collect and disseminate research data on their Sustainable food systems for food security efforts, while simultaneously increasing the impact of the support package on that same community.

Projectwide A djustments to the $\mathrm{C}$ ommunity Support Pack age M anagement System The way in which community partners received their share of funding from the Food Dignity project was via subawards from the primary grant recipient, the University of Wyoming, where Christine worked throughout the project. Via the subawards, funds were funneled to a site's 501(c)(3) federally tax exempt operating organization (as in the case of BMA, ENYF!, and FLV), or

\section{Feeding Laramie Valley, Albany County, Wyoming}

Feeding Laramie Valley (FLV) programs are dedicated to the mission and philosophy of sharing the best of what everyone has in order to create collaborative, community-led food systems that are sustainable, equitable, and just. A program of the grassroots nonprofit organization, Action Resources International, FLV is committed to working toward creating a sustainable and local food system and to promoting food security throughout the Rocky Mountain Region-with particular emphasis given to the community it calls home, Albany County, Wyoming. Since its founding in 2009 , FLV continues to address its mission through the development of new community gardens, increased food production efforts as well as growing, rescuing, and donating high-quality locally grown produce that is shared with individuals and families, with special focus on elders, children, and people living with chronic illness. With a broader goal of developing a just and secure food system, FLV offers a free summer lunch program in the summer, year-round educational workshops and events, and provides garden mentoring to people living with chronic health conditions. During its five-year participation as a community partner site with the Food Dignity research project, FLV established an in-depth, year-round intern and apprenticeship program for university students and community members of all ages from high school age upward. FLV also created a Community Voice J ournalism project through which community food project interviews are conducted, recorded, and disseminated as a means of maintaining the community's rich history with producing and distributing healthy, fresh produce in the challenging geographical environment of the high elevation and short growing season of Laramie Valley and the surrounding mountains. All FLV programs are predicated on the belief that people who are living with the problems FLV is working to help address are the same people who hold the expertise and the answers to those problems. 
to the agency through which the community partner operated (as in the case of D DF and WCP).

The USDA-AFRI grants funds were being provided to the University of Wyoming on a reimbursement basis, meaning that funds must be first expended, then invoiced for reimbursement-a process that could take several months or more to be completed for each outlay of cash. This was an immediate challenge for all the community partners, but in particular for the independent CBO s--BMA, ENYF! and FLV--that were all operating on tight budgets with little to no cash reserves with the capacity to carry programming until reimbursements were received. On a related matter, the University of Wyoming (UW) was proposing to release funds on a quarterly, equal amount basis, which did not always line up with how the programs operated. In particular, since all five community partner sites were involved in one way or another with food production work, the majority of their cash outlay occurred between the months of April and O ctober.

In response to community partner concerns and feedback, Christine negotiated with UW's research office on behalf of the project's community partners. She succeeded in changing how subawarded grant funds were distributed to them. Included in their subaward contracts was an agreement to advance funds on a quarterly basis for the first year and on a semi-annual basis for subsequent years. Christine also worked with individual sites on developing a payment plan that reflected when specific funds would be needed, and UW agreed to allow for payment amounts to fluctuate throughout each project year.

One final up-front adjustment to all the Food Dignity project community support packages was the removal of the budgeted $10 \%$ indirect cost line item, which USD A-AFRI disallowed for the community partners on this particular grant. D etermined to provide some kind of administrative support, Christine negotiated to have those funds shifted to salary-wage support for a project administrator role.

That $10 \%$ of funds, which averaged US $\$ 5,800$ a year, was at the time (and to date remains so) a rare add-on in grants awarded to CBOs. Even as the allocation was excluded post-award by the finance offices at USDA-AFRI and moved, instead, to become a line item that supported program management staff time, it was a rare phenomenon for community organizers to receive grant funds that helped, to any degree at all, defray the very real costs associated with infrastructure administration. This particular line item was most especially felt and immediately appreciated by BMA, ENYF!, and FLV, all of which were painfully familiar with the scramble to keep the furnace rooms of their grassroots efforts running to support their work at the frontline.

Nevertheless, this seemingly small yet valuable acknowledgement of need on behalf of the Food Dignity community partners also served as a stark reminder of the vast inequity stretching between

Whole Community Project, Tompkins County (Ithaca), New York

A program of Cornell Cooperative Extension Tompkins County, Whole Community Project (WCP) was established to strengthen youth, adults, families, and communities through learning partnerships that put knowledge to work. The Food Dignity project's principal investigator (PI) and director, Christine Porter, became familiar with WCP's move into sustainable community food system work to increase food security as part of her own research as a Ph.D. student at Cornell. She and WCP's community organizer, Jemila Sequeira, shared conversations that helped frame the research questions of the Food Dignity research project. WCP was deeply invested in the often hidden social constructs behind poverty and food insecurity-in particular matters of equity related to race and class-ensuring that its widened reach into sustainable community food system work was driven by that awareness. Throughout the five years of the Food Dignity project implementation, WCP enriched its Gardens 4 Humanity project, its presence at the Congo Square Farmers Market in Ithaca, innovative mentoring programs, and ongoing community education programs leading to economic development within the community and in support of individual entrepreneurs. 
them and their academic counterparts. It's important to note here that the two major universities benefitted from biggest piece of the Food Dignity grant funds (just under US\$2 million, including indirect costs), and USD A permitted them to charge an indirect cost rate of $22 \%$, which supports the institutions' infrastructures.

\section{Budget L ine Item M odifications ${ }^{2}$} On the heels of the contractually and functionally important changes to the access of Food Dignity grant funds, there came additional questions and requests from community partners regarding their support package budgets. This suggests that Christine's proactive and positive response to initial financial concerns was perceived, in part, as an invitation to question and perhaps have the power to effect additional changes. That, connected to historic and individual experience with barriers that restrict funding, likely served as an impetus for the community partner sites to act on opportunity for change the moment it appeared.

\section{Salaries and wages}

As the Food Dignity project intervention components were rolled out at each community partner site, so too did the directors and organizers at those sites become aware that attaching project research needs to existing program operations came at a price. For example, one expected element of the project was to include the recording of SFS interventions through photography, video, narrative, and Photovoice ${ }^{3}$ projects. These labor, skill, and time intensive methodologies were attached to (and meant to be supported by) salary and wage line items in each community site budget.

The original budget design financially supported a $50 \%$ full-time equivalennt (FTE) position for a community organizer. Annual amounts varied from site to site, based on a fulltime rate proposed by Christine and accepted by

\footnotetext{
2 For additional detail and context, refer to Table 1 in this paper.

3 Photovoice is a process by which people can identify, represent, and enhance their community through a specific photographic technique. As a practice based in the production of knowledge, Photovoice has three main goals: (1) to enable
}

each CBO . Funding was also provided for parttime roles called community researchers and animators. The average amount across all sites allocated for the community organizer was US\$26,600 per year. For community researchers, the package allocated an average of US $\$ 12,900$ per year for five years, and animators were funded at an average rate of US\$2600 per year. Also, instead of animator funds, BMA was budgeted for farmers market managers. See Table 1 in Porter and Wechsler (2018) in this issue for details of the community support package funding lines.

If the budget items in the Food Dignity project community support packages were dedicated entirely to deliverables (data collection, analysis, and dissemination) of the research project itself-and if those deliverables were only attached to interventions already in place at each site-- the allocations might have been sufficient to carry out the project's research objectives. But because the action research aspect of the project included capacity building, support, and the development of new intervention tools (notably the minigrants) as part of those objectives, the project expectations of the community partners were not met by the amount of funding provided-and in particular, not within the constraints of how the budget was first detailed.

Without exception, all five community partner sites determined that attempting to piecemeal salaries and wages as delineated in the project's predetermined line item budget was not practical. It added financial and management burdens to the site's existing structure and did not improve levels of participation in the community.

According to D avid Vigil, director for ENYF! beginning in the fourth year of the Food Dignity project, the original design of their budget was to provide no salary support for then director, Sarita D aftary-Steel. They were operating under the assumption that, by hiring a 50\% FTE community

people to record and reflect their community's strengths and concerns, (2) to promote critical dialogue and knowledge about important issues through large and small group discussion of photographs, and (3) to reach policymakers. (Wang \& Burris, 1997). 
organizer, all Food Dignity project requirements would be taken care of. Instead, the relative inexperience of the new community organizer cost time (and money) in training and supervision hours. By shifting funds between line items, they managed the problem by covering $15 \%$ FTE of Sarita's salary with Food Dignity project funds. They then filled the gap left in the community organizer's salary by shifting some of the researcher and animator funds to that position (held by D aryl Marshall throughout the length of the project).

That chain of decision-making regarding shifting allocations in the salaries and wages category of ENYF!'s project budget was also backed by lessons learned in trying to divide small amounts of money among community members as designed in the original budget.

In regard to offering small paid positions for photographers to help fill the project-prescribed roles of researchers and animators, D avid said, "we struggled with having a very part-time position like that. It evolved so [the person hired] ended up having a much more narrow role with us, limited to photography, but we even struggled with getting that organized." Another community member hired to collect data primarily through photography, D avid added, was "so part-time, she ended up not being able to devote the right kind of attention to it."

Similar shifts and the reasoning behind them were made at the other Food Dignity sites as well. Blue Mountain Associates created a part-time staff position called Community Researcher in response to the community researchers and animators budget lines, a position held by Jim Sutter. According to Jim, "originally the photographic collection process was to include the facilitation of two 'Photovoice' sessions in year one and another two sessions in year five. D ue to the [implementation choices] of the other four [Food Dignity project community partners] and other obstacles, it was decided to complete the goals of the Photovoice, but entirely on a local basis as set up by the Community Researcher position and the [BMA] steering committee."

Both DDF and FLV made similar decisions to merge, mix, and match the roles and funding allocations for the community organizer, commu- nity researchers, and animators set forth in their original project budgets. They based their decisions on how their sites were operating and what they were attempting to accomplish at any given time within the five-year project.

In my personal experience at Feeding Laramie Valley, being able to combine these temporary roles and assign them in varying ways as we made our way through the project allowed me to envision the permanent staff needs of the organization, to utilize project funds almost as piloting placeholders for staff positions, and to bring in community members to help launch that vision. To us, this approach, along with collecting project-related data, seemed to encapsulate the meaning of community organizer, researcher, and animator. Two of our current full-time employees- our food production coordinator, Reece $\mathrm{O}$ wens, and our community engagement coordinator, Lina D unning-- began their paid work with FLV as a result of how we managed those particular Food Dignity project funds.

Dig D eep Farms experienced those funds very differently. Regarding researchers and animators, director Marty Neideffer pointed out, "conceptually those things made some sense, but practically they didn't at all--especially at a time when D ig Deep was so new."

In keeping with the mainstay of her objectives, one that always placed equity and social justice in a foundational position within any program effort, Jemila Sequeira of WCP articulated her view of how the Food D ignity project community support package, as designed, fell short in enabling the community partner sites to succeed in the project as they would have liked.

"One of the consistent challenges," she said, "was the language used in the project--such as animators, interns, researchers, etc. They all needed more clarification. What is an animator? I remember using the word 'catalyst' to describe the process, community members were offended, but they didn't talk to me about it. I realized then that the [Food Dignity project] grant language needed to be changed to make sense for the community members. It was challenging in the beginning to even find a common page where we could agree what 'dignity' meant for each of us." 
Travel and participant support costs

One section of the community support package that proved particularly helpful to the community partners was that of travel and participant support costs. In the course of her graduate studies, Christine Porter had fully absorbed what she had been told about a common challenge among grassroots organizations eager to include community members in leadership and direct advisory roles as programs were developed and implemented. It was not uncommon for the engagement of community members to be truncated or not at all viable due to lack of practical support for people living with limited means. The costs of transportation, child or elder care, time taken away from paying jobs were all factors that often made participation difficult or even impossible.

With great aplomb, the community partners utilized these funds to reimburse mileage, provide food at meetings, and pay out stipends (that typically ranged from US\$50 to US\$100 for a two-hour meeting) in recognition of the value of a community member's knowledge base and skill set, and the time it took for them to share it in furtherance of the project's goals. Ironically, it was the one community site associated with a universityconnected institution that often ran into trouble accessing and distributing those funds to the people for whom they were intended. WCP found itself and its community participants often having to file copious amounts of paperwork, then wait for weeks or more before receiving their small reimbursement or stipend checks.

\section{Minigrants}

Unlike other aspects of the Food Dignity project's community support package, the minigrant component prescribed a specific program to be implemented at each partner site (see Hargraves, 2018, this issue). The potential and possibilities associated with having US $\$ 30,000$ over five years to experiment with how that amount of money could be invested in community food projects were well received by the Food D ignity project's community partners. The minigrant line item was one that provided the greatest opportunity for the project's CBO s to create a new program that would have a direct impact on their communities.
As written in the original grant proposal, it was expected that a steering committee made up of community members would be part of soliciting, reviewing, and awarding individual minigrant applications. ENYF! and BMA followed this basic design with a wide range of grant types. FLV modified the process by creating a progression model through which first-round grant recipients became grantmakers in a follow-up round. For WCP, grants were allocated to specifically support capacity development among individuals not typically invited to leadership positions and were awarded individually by the Community O rganizer in most years, though there was a formal steering committee for awarding grants in the third year of the project. DDF, in the early stages of creating constituent-driven frontline work, held back its utilization of the minigrant funding and drafted a couple of program models before finding an appropriate community-based use in the fourth and fifth years of the Food D ignity project.

The minigrant line item in the community support package became a reflection of each community partner site's ability to creatively manage limited resources in a way that best suited an array of local community needs. This included a layered implementation process that provided mentoring, support, entrepreneurial capacity building, and leadership recognition and development aspects along the way. Having been given backing for being flexible in their utilization of the package, five community partner sites pulled out the stops in their innovative design and realization of what they soon began to call the Food Dignity project's minigrant program.

\section{L eadership development funds}

Even as great effort was made to honor and respect the exigent duality of a combined academic and community approach to the Food Dignity project, the friction sometimes created as a result of its built-in dichotomy and inequities was not easily managed. The community partners were limited in their choices and in the power of their individual and collective voices. It was within the day-to-day operations of their frontline work that they maintained autonomy and held fast to their own sense of dignity. As they began to understand 
the flexibility of the community support package once it was in their hands and developed an ability to articulate to Christine their need for changes in the budget structure, an opportunity for significant change was brought into play.

Leadership among the community partners had begun to comfortably point out that there was great inequity exhibited by how the project's funding distribution was weighted heavily on the academic side. At about the same time, Christine let it be known that there were funds at the project level that she had the ability to reallocate. This gradual shift in perspectives on both sides led to a community request for additional funds for each site that would dedicated to independent leadership development and capacity building projects.

A small amount of funds originally under the complete control of the project's central administration was transferred to the community support package in the form of what was called "Leadership D evelopment (LD) Funds." After a pilot of US\$5000 in LD funds for each CBO in the project's second year, each site was given an additional US\$21,000 (funded at US\$7000/ year for the last three years of the grant) to be used for projects that helped support sustainable capacity building in their communities.

In a team-developed and approved process, each site was required to submit a detailed proposal and time-line for each use of the LD funds, which had to ultimately be approved by Christine and myself. Projects ranged from workplace culture improvements to statewide community food summit funding and a variety of other projects that will be available for review on the Food Dignity project website.

\section{Concluding Reflections and $\mathrm{Observations}$}

At the start of the Food Dignity research project, Christine responded to my query about her expectations for the project by saying that she expected to be surprised and to learn a great deal she hadn't yet imagined. Those expectations were met along a road that was often rocky, filled with pot-holes, and circuitous. The community partners proved to be a stalwart bunch that held great vision they played out in unexpected, ingenious - and sometimes contentious- ways.
Money was often the devil of the details as the community-based members of the Food Dignity research team scrambled to live up to their obligations to the project while simultaneously providing something of value to their communities (all in addition to everything they were already doing). The small percentage ( $7 \%$ ) of the overall project funding that went to each community partner site served as a reminder that, along with the unique opportunities that came with being a community partner on the Food D ignity project team, there were project realities that replicated a long history of inequities. These inequities included those of power and privilege that exist between the academy and the communities it mines for material upon which academic careers and recognition are built.

For five years, I learned from an extraordinary group of community activists who were deeply invested in helping to establish viable methods for increasing food security, sovereignty, and justice in their local communities. They were equally committed to generously sharing what they learned along the way. These people taught me more about food production, preservation, distribution, cooking, and eating - as well as how these essential aspects of human survival relate to our individual, cultural, social, and political experiences in lifethan I could have ever imagined when I agreed to be part of the Food Dignity research project. As I write, I've now had more than seven years of involvement with the project, and I expect to be learning from what it produced for many more years to come.

Above all else, I value the in-person time I got to spend with members of the Food Dignity project team, very often on site in the communities they love. I'm not alone in feeling this way. As the project's five-year span drew to a close, I began to ask the project's key community partners questions of reflection regarding their experiences with the Food Dignity project. All of them talked about how extraordinary it was to be part of the nearly week-long national team meetings (a total of seven of them), for which all direct expenses were covered by the project.

Some of the most difficult conversations and struggles took place at those meetings as project partners tried to hash out our differences and come 
to some kind of consensus over what is needed-or even possible--in community food systems work and in the current, dominant, food-access structures. We also found common ground to stand on when it came to at least a theoretical view that availability and adequate access at all times to the sufficient amount of safe and nutritious food needed to maintain a healthy and active life should be considered a right, not a privilege.

The budget funds from the Food Dignity project's community support package were alternately generous and insufficient in the daily working lives of its community partner sites. In a world that values institutionally-based knowledge over the first person expertise of lived experience, grassroots activists struggle constantly with the desire to show gratitude for all support that comes our way and the need to push back against the oppressive realities of being perpetually underfunded (especially in comparison to our academic "partners") and marginalized.

The Food D ignity project's community support package did not provide funding capable of establishing a direct route to program sustainability for its community partner sites. It did, however, provide a path to sustainability and increased mainstream credibility through its leveraging potential. Several of the sites subsequently received federal and private foundation grant funds substantial enough to move their programs forward, an achievement no doubt aided by the status achieved by their key involvement in a major, awardwinning, national action research project. Many of the community partner team members authored or co-authored published papers associated with their work with the Food Dignity project, and many were presenters or co-presenters at local and national conferences.

Greater than the direct results we're able to report from the work done within the Food Dignity action research project is the opportunity it has unearthed to discuss, plan, and enact systemic change moving forward. How the knowledge and work of community-based activists, in particular those who have themselves experienced the problems they are trying to address, is supported (or not) through funding is directly related to their ability to succeed in community-based, social change work.

The Food Dignity action research project itself could have looked very different, and might have accomplished even more, if the community support package had been accessed, designed, developed, and distributed differently. The questions that can arise out of that kind of imagining are limitless. Had the community partners been collectively involved with the design and distribution of the Food Dignity project funds from the start, had they themselves been given the opportunity to competitively apply for the funds, had the academic team served as subawardees with clearly defined and limited roles in service to the community partners, had the $\sim$ US $\$ 400,000$ of indirect costs been distributed among the community partner sites, etc., etc., how would the process and results of this project's objectives turned out?

Until the embedded belief that the knowledge hierarchy is dominated by the academy is fully dismantled, and until the academic system is prepared to relinquish its out-of-balance share of the power and privilege (including funding) attached to that disparity, the possibility of achieving an equitable, and therefore true, communityacademic partnership remains out of reach.

Yet, as history at large and the recounting of the many elements of the Food Dignity action research project have shown, the long reach for justice is served well by the courageous, countless steps taken by those who dare to imagine that change is possible.

I have no doubt that most of the community members directly involved with the Food Dignity project will continue to acknowledge the project's contribution to their life's work. I'm equally certain that the greatest achievements of the Food Dignity project are rooted in the toil, courage, and brilliance of the community members who made those achievements possible. 


\section{References}

Daftary-Steel, S. (2018). Entering into a community-university collaboration: Reflections from East New York Farms! Journal of A griculture, F ood Systems, and C ommunity D evelopment 8(Suppl. 1), 5-7. https:// doi.org/ 10.5304/ jafscd.2018.08A.013

Hargraves, M. (2018). Learning from community-designed minigrant programs in the Food Dignity project. Journal of A griculture, F ood Systems, and Community D evelopment 8(Suppl. 1), 117-146. https:/ / doi.org/ 10.5304/ jafscd.2018.08A.007

Neideffer, M. (2018). Entering into a community-university collaboration: Reflections from Dig D eep Farms. Journal of A griculture, Food Systems, and Community D evelopment 8(Suppl. 1), 23-25. https:/ / doi.org/ 10.5304/ jafscd.2018.08A.011

Porter, C. M., \& Wechsler, A. (2018). Follow the money: Resource allocation and academic supremacy among community and university partners in Food D ignity. Journal of A griaulture, Food Systems, and C ommunity D evelopment 8(Suppl. 1), 63-82. https:/ / doi.org/ 10.5304/ jafscd.2018.08A.006

Sequeira, E. J. (2018). Entering into a community-university collaboration: Reflections from Whole Community Project. Journal of A griculture, Food Systems, and Community D evelopment 8(Suppl. 1), 9-11. https:// doi.org/ 10.5304/jafscd.2018.08A.014

Sutter, V. J. (2018). Entering into a community-university collaboration: Reflections from Blue Mountain Associates. Journal of A griaulture, Food Systems, and C ommunity D evelopment 8(Suppl. 1), 13-15. https:// doi.org/ 10.5304/jafscd.2018.08A.012

Wang, C., \& Burris, M. A. (1997). Photovoice: Concept, methodology, and use for participatory needs assessment. H ealth E ducation \& Behavior, 24(3), 369-387. https:// doi.org/ 10.1177/ 109019819702400309

Woodsum, G. M. (2018). Entering into a community-university collaboration: Reflections from Feeding Laramie Valley. Journal of A griaulture, Food Systems, and C ommunity D evelopment 8(Suppl. 1), 17-22. https:// doi.org/ 10.5304/jafscd.2018.08A.017 